\title{
PT, eleições e editoriais da grande imprensa (1989-2014)
}

\author{
Fernando Antônio Azevedo ${ }^{1}$
}

O artigo examina, a partir do conceito de paralelismo político, a relação da "grande imprensa" do Brasil, formada pelos três grandes diários de circulação nacional, O Estado de S. Paulo, Folha de S. Paulo e O Globo, com o petismo entre 1989 e 2014. A referência empírica são os editoriais publicados pelos jornais durante as sete últimas eleições presidenciais que têm como objeto o PT e seus candidatos. Os textos foram avaliados através da metodologia da análise de valência e agrupados em pacotes interpretativos. Os resultados mostram a predominância de editoriais negativos e o uso dos enquadramentos "populista" e/ou "corrupto" na narrativa sobre o PT e o petismo, tanto no período pré-governamental quanto no governamental do PT no plano federal.

Palavras-chave: mídia; imprensa; editoriais; partido; eleições; PT; antipetismo

\section{Introdução}

Este artigo tem como tema a relação dos três principais jornais de referência do Brasil (O Globo, O Estado de S. Paulo e Folha de S. Paulo) com o Partido dos Trabalhadores (PT) através da análise dos seus editoriais publicados durante as eleições presidenciais entre 1989 e 2014. Essas publicações fazem parte da chamada "grande imprensa" e no passado tiveram intensa atuação política apoiando as forças de centro-direita contra o governo nacionalista de Getúlio Vargas (1951-1954) e o governo reformista de João Goulart, o Jango (1961-1964), ambos ligados ao Partido Trabalhista Brasileiro (PTB), de centro-esquerda (Sodré, 1999; Abreu, 2008; Carvalho, 2013; Goldstein, 2017). Todos esses jornais apoiaram o golpe militar de 1964 e o regime autoritário, com o dissenso posterior de $O$ Estado de S. Paulo, após o aprofundamento da ditadura com a edição do Ato Institucional no 5 em 1968. A partir da redemocratização e da instauração da Nova República, em 1985, os veículos passaram a conviver com um novo sistema partidário e uma nova dinâmica política que, a partir de 1994, polarizou a disputa eleitoral presidencial entre as forças de centro-esquerda, lideradas pelo PT, e as de centro-direita, comandadas pelo Partido da Social Democracia Brasileira (PSDB). Uma revisão da literatura (Guimarães e Vieira, 1989; Lima, 1990; Albuquerque, 1994; Rubim, 1985; Aguiar, 1995; Jorge, 1997;

1 Programa de Pós-Graduação em Ciência Política (PPGPol). Universidade Federal de São Carlos, São Carlos (SP), Brasil. E-mail: <f.azevedo@me.com>. Orcid: <https://orcid.org/0000-0003-2696-7589>. 
Rubim e Azevedo, 1998; Miguel, 1999; Azevedo, 2000, 2009, 2011; Aldé, 2003; Chaia, 2004; Rubim e Colling, 2004; Fonseca, 2005; Aldé, Mendes e Figueiredo, 2007) sobre a cobertura das eleições presidenciais nesse período mostra que a maioria das pesquisas e levantamentos apontou que os jornais, e a mídia de um modo geral, atuaram em variados graus com viés partidário, favorecendo assim direta ou indiretamente os candidatos antipetistas nos pleitos presidenciais. Não conheço, porém, salvo engano, um estudo longitudinal que analise o comportamento dos jornais e mostre tendências e continuidades abrangendo todas as eleições presidenciais realizadas até o momento. Este artigo tenta suprir parcialmente essa lacuna. Seu objetivo principal é discutir o comportamento da imprensa mainstream a partir do conceito de paralelismo político (Hallin e Mancini, 2010), tendo como referência empírica a relação dos jornais com o PT e o petismo a partir da pergunta: na atual quadra democrática, a grande imprensa brasileira atuou de modo paralelo ao sistema político, assumindo posições político-ideológicas como o fez no período democrático de 1945-1964?

A pergunta tem pertinência e relevância no contexto informacional brasileiro. 0 sistema de mídia é oligopolizado e controlado basicamente por quatro famílias (Marinho/Grupo Globo, Mesquita/Grupo Estadão, Frias/Grupo Folha e Civita/Grupo Abril) que detêm a propriedade cruzada de jornais, revistas, redes de televisão, sites e portais. Desse modo, a maior parte do fluxo da informação política é monopolizada pelos grandes grupos midiáticos e as fontes alternativas de informação, que Dahl (1989) aponta como um dos requisitos fundamentais da democracia representativa, ocupam um papel secundário (em geral em sites e blogs) e marginal do ponto de vista do seu impacto na formação da opinião pública. Nesse contexto, de um sistema de mídia concentrado e caracterizado por uma oferta de conteúdo político com baixa diversidade, a parcialidade da grande imprensa, pelo seu grande poder de agendamento (e ripple effect no noticiário televisivo e nas redes sociais), pode gerar assimetria informacional e potencialmente desequilibrar a disputa política e eleitoral ao vocalizar, reproduzir ou endossar argumentos e estratégias narrativas de grupos e partidos políticos.

É consenso na literatura da comunicação política recente, fortemente influenciada pelas teorias da agenda-setting e do framing, que a mídia tem grande poder de agenda ao selecionar e hierarquizar notícias e estabelecer enquadramentos e narrativas sobre fatos, acontecimentos e personagens. Como lembrou Cohen (1963, p. 120), a imprensa pode não ser eficaz em dizer como se deve pensar, porém tem grande capacidade em sugerir o que pensar. Ou seja, de tematizar e colocar, no centro da atenção pública, questões sobre as quais fornece também análises e interpretações produzidas a partir de enquadramentos narrativos. Dessa maneira, como observaram Lang e Lang (1959, p. 226) num texto sobre a influência da mídia nas campanhas eleitorais, as mídias constroem perspectivas, conformam as imagens dos candidatos e dos partidos e ajudam a destacar os conceitos em torno dos quais se desenvolverão as campanhas. 
PT, ELEIÇÕES E EDITORIAIS DA GRANDE IMPRENSA (1989-2014)

Portanto, no jogo político a mídia importa e muito. É ela que, nas democracias modernas e de massa - que Manin (1995) descreve como democracias de público -, ao lado das campanhas eleitorais, opera a mediação entre os atores políticos (partidos e candidatos) e os cidadãos e eleitores. $E$, em que pesem a centralidade da televisão nos meios de comunicação de massa com sua grande penetração no público e o avanço das novas mídias digitais, como a internet e as mídias sociais (Facebook, Youtube, Twitter, Instagram etc.), ainda são os jornais e as revistas de informação semanal as principais fontes de informação e agendamento da política. É dessa velha mídia que as principais notícias e os comentários têm origem e são replicados na televisão e nas novas mídias. Em outras palavras, a mídia impressa pauta não só a mídia eletrônica (rádio e televisão) como a mídia digital (internet e mídias sociais): como mostrei em outro trabalho (Azevedo, 2017, p. 27), a maior parte das notícias e dos artigos que trafegam nas novas mídias é originária de jornais e revistas impressos, o que, aliás, se pode comprovar simplesmente olhando os temas dos debates polarizados no Facebook. Assim, embora não seja a única fonte, a imprensa escrita pauta grande parte das questões políticas e as outras mídias repercutem, ampliam e disseminam os temas em debate, realimentando o fluxo de informação.

O conceito original de paralelismo político foi cunhado por Seymour-Ure (1974) na tentativa de definir, através da categoria paralelismo partido-imprensa, a convergência de interesses políticos entre jornais e partidos. Refinando o conceito, Blumler e Gurevitch (1975) propuseram uma escala de paralelismo político para abranger graus de intensidade (máximo, intenso, médio, baixo e zero) e situações que iam desde o controle vertical da publicação (imprensa partidária como a existente em alguns países da Europa no passado) até o jornalismo independente cuja referência normativa seria o modelo liberal do jornalismo comercial norte-americano. Por sua vez, mais recentemente, Hallin e Mancini (2010) revitalizaram o conceito explorando-o como uma das variáveis de análise dos modelos de sistema de mídia do mundo ocidental. Os referidos autores, inspirados nos pesquisadores que os precederam, descrevem cinco elementos ligados à prática do paralelismo político (conexões organizacionais, caráter partidário da audiência, conteúdo dos meios, atuação dos jornalistas na política e o jornalismo de comentário apoiado na concepção do jornalista como publicista) e os associam mais ao compartilhamento de crenças, valores e tendências políticas mais gerais do que à conexão um a um entre meios e partidos que caracterizou o jornalismo partidário do passado. Albuquerque (2012a, 2012b), por sua vez, propõe que paralelismo político e jornalismo independente sejam considerados como modelos históricos distintos. Sem entrar na discussão sobre os limites e alcances teóricos do conceito, assumo, aqui, a ideia de Hallin e Mancini de que o paralelismo político nos dias de hoje, marcado pelo predomínio do jornalismo comercial, se dá basicamente em torno do compartilhamento de crenças e valores ideológicos, de uma causa determinada ou uma agenda política contingencial capaz de associar e produzir convergências políticas entre jornais e partidos. 
Os jornais examinados têm, apesar do alto nível de profissionalização, independência comercial e adesão formal ao modelo de jornalismo centrado nas notícias e um vigoroso e extenso jornalismo de comentário através de editoriais, colunas e artigos que ocupam espaços destacados e possuem grande peso nas edições. Portanto, antes de tudo e principalmente, são jornais de opinião que valorizam o papel de seus publicistas, e seus editoriais ocupam um lugar nobre e de grande visibilidade. Como lembra Eilders (1997), a alma dos jornais está nos editoriais, que são o core jornalístico que emite e transmite a posição política das publicações e de seus proprietários. Nesse sentido, eles são a matéria-prima por excelência para avaliar o posicionamento político dos jornais.

A análise dos editoriais aqui procedida se estende de 1989 a 2014, perfazendo 25 anos e sete eleições presidenciais na atual quadra democrática. A amostragem foi circunscrita ao período eleitoral, tomando-se como referência o início da emissão da propaganda gratuita no rádio e na televisão (Horário Gratuito de Propaganda Eleitoral HGPE), iniciando a coleta dos editoriais 45 dias antes da data da eleição do primeiro turno e estendendo a observação até a data do segundo turno, quando for o caso². A escolha do período eleitoral contempla um momento que usualmente é de grande importância na vida democrática, como lembram Swanson e Mancini (1996), pois, durante as campanhas eleitorais, os temas políticos e o confronto de ideias e projetos entre os partidos e os candidatos assumem grande visibilidade e mobilizam a atenção dos eleitores.

O procedimento adotado para analisar e interpretar os dados baseia-se na metodologia da valência e dos pacotes interpretativos. A metodologia de análise de valência (MAV), também conhecida como slant analysis, sentiment analysis ou opinion mining, é utilizada internacionalmente em estudos de mídia em contextos eleitorais desde os anos 1950 para medir a valoração dos conteúdos da mídia em relação a um determinado objeto $^{3}$.

Os pacotes interpretativos, por sua vez, são baseados na teoria do enquadramento (Goffman, 1974). Na definição sintética de Entman (1993, p. 52), enquadrar é o processo de selecionar aspectos da realidade e torná-los mais salientes para produzir uma definição ou interpretação particular de um problema ou questão moral. Gitlin (1980), por outro lado, sublinha que o enquadramento é basicamente um esquema interpretativo que

\footnotetext{
2 A propaganda eleitoral no rádio e na televisão, regulada pela Lei no 7.773, de 8 de junho de 1989, tinha duração de 60 dias, porém, em 1998, ela foi reduzida para 45 dias. Por uma questão de padronização, o exame dos editoriais em cada período eleitoral obedeceu à regra dos 45 dias.

3 No presente artigo adotam-se as seguintes regras para analisar o material pesquisado: (1) a valência é positiva se o conteúdo analisado encerra uma avaliação ou menção de ordem pessoal, moral, política ou de desempenho nas funções públicas favorável a políticos ou avaliação e menção favorável de programas, projetos e ação de partidos ou governo; (2) a valência é negativa se o conteúdo analisado encerra uma avaliação ou menção de ordem pessoal, moral, política ou de desempenho nas funções públicas negativa a políticos e menção desfavorável na avaliação de programas, projetos e ação de partidos ou governo; (3) a valência é neutra se o conteúdo analisado não apresenta nem elementos positivos nem negativos na avaliação ou menção de ordem pessoal, moral, política ou de desempenho nas funções públicas a políticos ou na avaliação e menções a programas, projetos e ação de partidos ou governo. Em caso de matérias ambivalentes, em que há equilíbrio entre elementos positivos e negativos, o conteúdo foi considerado neutro. Sobre a metodologia de análise de valência e seu uso na literatura internacional, ver Feres (2016).
} 
PT, ELEIÇÕES E EDITORIAIS DA GRANDE IMPRENSA (1989-2014)

estabelece um eixo e organiza a narrativa jornalística ao longo do tempo, permitindo, assim, uma articulação de sentido entre eventos e personagens que ultrapassa os relatos episódicos. Portanto, como resumem Gamson e Modigliani (1989, p. 143), os pacotes interpretativos devem ser vistos como uma ideia organizadora central ou um enredo que produz sentido para o desdobramento de uma série de eventos, promovendo uma conexão entre eles.

O artigo está dividido em três seções. Na primeira, "Resumo histórico e político dos jornais", apresento um perfil dos jornais pesquisados; na segunda, "Os editoriais dos jornais: 1989-2014", analiso os dados; e, finalmente, na terceira, a "Conclusão", comparo os jornais e sintetizo os achados da pesquisa.

\section{Resumo histórico e político dos jornais}

\section{O Globo}

O jornal foi fundado no Rio de Janeiro em 1925, circulando como vespertino até 1962, quando passou a ser matutino. Entre os anos 1930 e 1980, o veículo se tornou o diário de maior circulação no Brasil, batendo concorrentes mais antigos e tradicionais. Sua ascensão como um dos principais jornais do país se deu paralelamente à formação das Organizações Globo, um conglomerado de mídia que paulatinamente agregou rádios e revistas (anos 1940) e televisão (anos 1960). Hoje, o Grupo Globo é o maior conglomerado de mídia do Brasil, liderando de forma absoluta a audiência da rede aberta (TV Globo e suas afiliadas), com importante presença na TV fechada, através da Globosat (Globonews, GNT, Multishow, Telecine, SporTV, entre outros) e no sistema radiofônico (rádios Globo e $C B N$ ), bem como nas novas mídias digitais (portal $G 1$ ) 4 . Sua influência na imprensa escrita não se limita ao Globo: o grupo edita também, no Rio, o jornal Extra, de perfil popular, e o Valor Econômico, diário especializado em economia e finanças e líder em seu segmento, além da revista Época, que concorre com Veja, IstoÉ e Carta Capital no mercado das revistas de informação semanal. Possui, ainda, a Rio Gráfica Editora, que publica livros e inúmeras revistas para público segmentado.

O Globo, ao longo da sua existência, tem assumido posições que permitem classificá-lo como um jornal liberal em relação às questões econômicas (pró-mercado e crítico do estatismo e do nacionalismo econômico) e, no plano político, alinhado com as posições liberal-conservadoras. Um retrospecto de seus posicionamentos políticos mostra que apoiou a Revolução Liberal de 1930, mas dois anos depois esteve com os constitucionalistas de 1932 contra Vargas e seu governo provisório. Após a redemocratização, em 1946, o embate político foi polarizado ideologicamente entre as

\footnotetext{
4 Com cinco emissoras próprias e 117 afiliadas, a Rede Globo chega a praticamente 100\% do território nacional, atingindo 5.485 municípios e $99,5 \%$ da população.
} 
forças de centro-direita e centro-esquerda, opondo os liberais (aglutinados na União Democrática Nacional - UDN) e os nacional-desenvolvimentistas, reunidos na aliança eleitoral formada pelo Partido Trabalhista Brasileiro (PTB) e o Partido Social Democrático (PSD), ambos criados por Vargas. O Globo, nesse período democrático, apoiou as forças liberais nos principais embates eleitorais e políticos. Na crise política de 1954, que terminou com o suicídio de Vargas em agosto daquele ano, o jornal cerrou fileiras com a oposição, embora tenha, por temer os riscos políticos e institucionais de um impeachment numa democracia recém-restaurada, se posicionado contra o afastamento do presidente, em março de 1954. Entretanto, a rádio Globo tinha se transformado numa tribuna aberta para os discursos inflamados de Carlos Lacerda, o principal líder da UDN, contra Vargas e seu governo. Em 1961, após a renúncia de Jânio Quadros, foi contra a posse do vice-presidente Jango e depois fez dura oposição ao seu governo e às bandeiras das reformas de base (especialmente a reforma agrária) defendidas pela esquerda brasileira. Em 1964, apoiou o golpe militar e publicou um editorial sob o título "Ressurge a Democracia"5, em que saudava a tomada do poder pelas Forças Armadas. Anos depois, em 1984, num editorial de primeira página6 ${ }^{6}$ assinado pelo próprio publisher do jornal, Roberto Marinho, o apoio à intervenção militar seria explicado como necessário para defender a democracia que estaria ameaçada e o apoio sem restrições ao Ato Institucional $n^{\circ} 5$, em 1968, justificado para conter "a irrupção da guerrilha urbana".

Com o retorno à democracia, em 1985, o jornal passou a apoiar uma agenda econômica liberal assumida, num primeiro momento, por Fernando Collor, e depois, por Fernando Henrique Cardoso (FHC) e os candidatos posteriores do PSDB.

O exame da lista de colunistas e articulistas do jornal mostra que a maioria deles concorda com a linha editorial e os valores do jornal, havendo pouco espaço para diversidade interna, opiniões divergentes e debate do ponto de vista político ou ideológico.

\section{O Estado de S. Paulo}

O Estadão foi fundado em 1875 e originalmente chamava-se A Província de S. Paulo $^{7}$. O jornal nasceu com posições políticas avançadas para a época, com um perfil antimonarquista e antiescravista, e entre seus colaboradores encontravam-se militantes da causa republicana e nomes conhecidos da vida intelectual como Euclides da Cunha, autor do clássico Os sertões. Depois do advento da República, com o fim das províncias monárquicas, o jornal assumiu o seu nome atual e passou a ser controlado exclusivamente por Júlio Mesquita, genro de um dos fundadores do diário, tornando-se então o principal diário paulista.

\footnotetext{
5 O Globo, 2/4/1964, p. 3.

${ }^{6} O$ Globo, 7/10/1984, p. 1.

7 Sobre o jornal e seu papel político, ver Capelato e Prado $(1980)$ e Capelato $(1986,1988)$.
} 
PT, ELEIÇÕES E EDITORIAIS DA GRANDE IMPRENSA (1989-2014)

Ao longo da República Velha (1989-1930), o jornal assumiu posição crítica em relação ao sistema eleitoral (voto aberto e fraudes eleitorais) e se engajou na campanha civilista que defendia um programa de reformas institucionais e modernização do país. Em 1930, aderiu à candidatura oposicionista de Vargas contra o candidato oficial das oligarquias dominantes. Porém, depois da Revolução de 1930, trocou de lado e apoiou o movimento constitucionalista de 1932, deflagrado pelas elites paulistas contra o governo provisório de Vargas, defendendo a constitucionalização do país e a realização de eleições. Com a decretação da ditadura do Estado Novo, em 1937, o jornal passa a fazer uma oposição aberta ao novo regime. Como represália, é censurado e, em março de 1940, sofre uma intervenção que se prolongaria por cinco anos. Encontra-se, nesse episódio, a origem do visceral antigetulismo que o jornal iria cultivar nos primeiros anos da quadra democrática que se inicia em 1946.

O antigetulismo do período ditatorial se transformaria, na nova quadra democrática, no combate ao populismo identificado com o trabalhismo varguista no início dos anos 1950 e, mais adiante, com o trabalhismo reformista dos anos 1960 durante o governo Jango. Desse modo, fez oposição aos governos Vargas (1951-1954) e Jango (1961-1964) e apoiou as passeatas contra este último ("Marcha com Deus pela família e pela liberdade") e o golpe militar de 1964. O apoio ao novo regime seria, porém, condicional. O aprofundamento do regime autoritário, com a edição do AI-5 em 13 de dezembro de 1968, frustrou a expectativa da família Mesquita de uma rápida devolução do poder aos civis nos limites de uma democracia restrita, expurgada das correntes de esquerda da antiga ordem política. Nesse sentido, o jornal demarca sua posição com a publicação de um duro editorial ("Instituições em frangalhos") ${ }^{8}$, assinado pelo publisher Júlio Mesquita Neto, que provocou o recolhimento da edição e colocou o jornal sob censura.

Uma retrospectiva da trajetória editorial ao longo do tempo mostra que o jornal viveu duas fases distintas. Nasce abolicionista e republicano e, na primeira metade do século XX, apoia a Revolução de 30 e se contrapõe ao Estado Novo getulista em nome dos princípios políticos liberais e democráticos. Mas abandona esses princípios ao apoiar o golpe militar de 64, embora o fizesse ao lado de todos os principais jornais do país (com exceção da Última Hora) que cerraram fileira pela deposição do governo Jango. Com a redemocratização em 1985 e o retorno das eleições diretas em 1989, o Estadão apoiou de forma reiterada todos os candidatos presidenciais de centro-direita que polarizaram com os candidatos do Partido dos Trabalhadores.

O exame das edições do jornal que circulam atualmente mostra que suas páginas de opinião possuem grande peso em relação às páginas informativas e nelas há pouco lugar para a diversidade interna, o contraditório e o debate de ideias, os valores e projetos políticos e ideológicos opostos, prevalecendo visões liberais ou conservadoras que estruturam as tendências políticas de centro-direita.

8 O Estado de S. Paulo, 13/12/1968, p. 2. 
A Folha ${ }^{9}$ faz parte de um grupo empresarial que edita o jornal e publica também Agora São Paulo, jornal popular que circula na capital paulista. O grupo também é proprietário de um dos maiores portais do país, o UOL, que abriga a edição digital da Folha, e atua também no segmento editorial, através da Folha Gráfica e da Editora Publifolha.

O jornal foi criado, em 1960, a partir da fusão de duas publicações: Folha da Noite e Folha da Manhã. A primeira, um jornal vespertino, circulou a partir de 1921 e, com uma linguagem jornalística mais popular e informativa, tinha como público-alvo leitores da classe média baixa e trabalhadores urbanos. Em 1925, os proprietários lançaram uma edição matutina, Folha da Manhã, com o mesmo perfil editorial e de audiência. Portanto, ambas as publicações ocupavam um segmento do mercado de informação não contemplado pelo Estadão, cujo público por excelência era a elite paulista.

Em 1930, ambas as publicações se posicionaram contra a Revolução e a favor da manutenção da velha ordem oligárquica e, com o golpe de 1937 e a instauração do Estado Novo, se colocaram na oposição à ditadura. Vargas, interessado em eliminar os focos de oposição na imprensa, estimulou a compra dos dois jornais por um grupo de empresários, que repagina a Folha da Manhã, lança uma terceira publicação diária (Folha da Tarde) e muda a orientação política em favor do governo. Em 1960, as três publicações são fundidas numa só, nascendo, então, a Folha de S. Paulo, que, em 1961, foi finalmente adquirida pelos empresários Octávio Frias de Oliveira e Carlos Caldeira Filho. Ao longo das duas décadas seguintes, os novos proprietários modernizaram o jornal (foi o primeiro veículo impresso em offset da América Latina), ampliaram sua circulação e suas receitas publicitárias e passaram a disputar a liderança da grande imprensa diária com $O$ Estado de S. Paulo e O Globo.

Nessa nova fase, o jornal atravessaria dois períodos bem distintos do ponto de vista político. Entre os anos 1960 e meados de 1970, o jornal apoiou o golpe de 64 e o regime militar, que recebeu uma adesão incondicional dele em sua primeira década de existência. O segundo período tem início com as reformas gráficas e editoriais, a partir de 1976, que renovou o jornal e a equipe de colaboradores e redefiniu seu target, elegendo os segmentos mais intelectualizados e progressistas do ponto de vista político como seu público leitor preferencial. Essas mudanças se dão num período marcado pela abertura política, em que a luta pela anistia e pela redemocratização começava a tomar impulso no país e a ganhar o coração e as mentes da classe média. Reposicionado editorialmente, valorizando o pluralismo e o debate de ideias, o jornal cresceu nos segmentos da audiência mais jovem e de classe média, e apoiou a luta em favor da anistia, da Constituinte e das eleições diretas, fazendo coberturas extensas de episódios políticos críticos para o regime militar e aderindo à campanha das "Diretas Já", que recebeu grande apoio da publicação.

9 Sobre o jornal e sua participação política, ver Goldstein (1987), Taschner (1992) e Matos (2008). 
PT, ELEIÇÕES E EDITORIAIS DA GRANDE IMPRENSA (1989-2014)

O jornal mantém, nos dias atuais, a mesma linha editorial e a política de diversidade interna, sendo, dos três grandes diários, o mais aberto ao debate e ao confronto de ideias. Com essas características, hoje está localizado mais ao centro do que à direita do espectro político, mas certamente a sua definição editorial mais precisa seria a de uma publicação alinhada com os ideários liberais na política e na economia, mas comprometida com uma audiência menos conservadora, que não era contemplada pelos seus concorrentes diretos.

\section{Os editoriais dos jornais: 1989-2014}

A pesquisa levantou 3.164 editoriais dos quais $937(29,6 \%)$ tinham como tema central o PT, como se pode ver na Tabela 1:

Tabela 1

Número de editoriais dos jornais e relacionados ao PT por ano

\begin{tabular}{|l|c|c|c|c|c|c|c|c|c|}
\hline \multirow{3}{*}{ Ano } & \multicolumn{9}{|c|}{ Editoriais } \\
\cline { 2 - 10 } & \multicolumn{3}{|c|}{ O Globo } & \multicolumn{2}{c|}{ Folha de S. Paulo } & \multicolumn{3}{c|}{ O Estado de S. Paulo } \\
\cline { 2 - 10 } & Total & PT & \% & Total & PT & \% & Total & PT & $\%$ \\
\hline 1989 & 93 & 8 & 8,6 & 276 & 46 & 16,7 & 263 & 66 & 25,1 \\
\hline 1994 & 61 & 2 & 3,3 & & & & 225 & 23 & 10,2 \\
\hline 1998 & 84 & 1 & 1,2 & 120 & 2 & 1,7 & 125 & 9 & 7,2 \\
\hline 2002 & 100 & 7 & 7 & 182 & 26 & 14,3 & 198 & 33 & 16,7 \\
\hline 2006 & 125 & 56 & 44,8 & 148 & 62 & 41,9 & 222 & 131 & 59 \\
\hline 2010 & 135 & 68 & 50,4 & 142 & 65 & 45,8 & 222 & 100 & 45 \\
\hline 2014 & 113 & 56 & 49,6 & 132 & 54 & 40,9 & 195 & 122 & 62,6 \\
\hline Total & 711 & 198 & 27,8 & 1.000 & 255 & 25,5 & 1.453 & 484 & 33,3 \\
\hline
\end{tabular}

Fonte: Elaboração própria com base em Azevedo (2017).

O partido foi objeto de assunto desde a eleição de 1989, da qual foi finalista, mas, como seria de esperar, os jornais dedicaram maior atenção ao PT a partir da sua chegada ao poder, em 2003. Como se pode observar nos dados da Tabela 1, a atenção dos jornais aumenta exponencialmente a partir de 2006, ano da reeleição de Lula e de uma campanha eleitoral que teve o escândalo do Mensalão como centro. O diário que mais explorou questões relacionadas ao PT foi o Estadão, seguido da Folha e d'O Globo.

Os editoriais do Globo

Dos 711 editoriais publicados, $27,8 \%$ foram sobre questões ligadas direta ou indiretamente ao PT, a seus candidatos ou ao governo petista. Contudo, esse percentual total não revela a distribuição desses editoriais nos anos mais recentes. Como pode-se

\footnotetext{
10 Não foi possível a coleta do ano de 1994, pois os editoriais estavam ilegíveis no arquivo digital da Folha de S. Paulo.
} 
observar na Tabela 2, O Globo explorou em 44,8\% (em 2006), 50,4\% (em 2010) e 49,6\% (em 2014) dos seus editoriais assuntos que tinham relação com o petismo. Esse alto nível de atenção concentrado nesses três episódios eleitorais, correlacionado com o alto nível de valências negativas nos editoriais a partir de 2006, indica que o jornal adotou uma posição mais crítica em relação ao petismo quando o PT assumiu o poder. Esse dado é corroborado quando confrontado com os números referentes à eleição de 2002, ocasião em que os editoriais são em sua maioria positivos e neutros. Porém, esse pleito foi, como observaram vários analistas, marcado pela trégua ${ }^{11}$ entre a mídia e o candidato petista. Nas eleições anteriores (1989, 1994 e 1998), o jornal publicou poucos editoriais tendo o PT como tema, mas todos negativos, como mostram os dados da Tabela 2:

Tabela 2

Editoriais relacionados ao PT e valência por ano - 0 Globo

\begin{tabular}{|c|c|c|c|c|c|c|c|c|c|}
\hline \multirow{3}{*}{ Ano } & \multirow{3}{*}{$\begin{array}{c}\text { Número } \\
\text { de } \\
\text { editoriais }\end{array}$} & \multirow{2}{*}{\multicolumn{2}{|c|}{$\begin{array}{c}\text { Relacionados } \\
\text { ao PT }\end{array}$}} & \multicolumn{6}{|c|}{ Valências } \\
\hline & & & & \multicolumn{2}{|c|}{ Positiva } & \multicolumn{2}{|c|}{ Negativa } & \multicolumn{2}{|c|}{ Neutra } \\
\hline & & $\mathbf{N}$ & $\%$ & $\mathbf{N}$ & $\%$ & $\mathbf{N}$ & $\%$ & $\mathbf{N}$ & $\%$ \\
\hline 1989 & 93 & 8 & 8,6 & 0 & 0 & 8 & 100 & 0 & 0 \\
\hline 1994 & 61 & 2 & 3,3 & 0 & 0 & 2 & 100 & 0 & 0 \\
\hline 1998 & 84 & 1 & 1,2 & 0 & 0 & 1 & 100 & 0 & 0 \\
\hline 2002 & 100 & 7 & 7 & 3 & 42,9 & 1 & 14,3 & 3 & 42,9 \\
\hline 2006 & 125 & 56 & 44,8 & 2 & 3,6 & 47 & 83,9 & 7 & 12,5 \\
\hline 2010 & 135 & 68 & 50,4 & 2 & 2,9 & 61 & 89,7 & 6 & 8,8 \\
\hline 2014 & 113 & 56 & 49,6 & 2 & 3,6 & 52 & 92,9 & 1 & 1,8 \\
\hline Total & 711 & 198 & 27,8 & 9 & 4,5 & 172 & 86,9 & 17 & 8,6 \\
\hline
\end{tabular}

Fonte: Elaboração própria com base em Azevedo (2017).

Visualizando-se em conjunto todos os anos, o saldo é francamente desfavorável para os petistas: o jornal publicou $86,9 \%$ de editoriais negativos contra apenas $4,5 \%$ positivos e $8,6 \%$ neutros.

Os dados da Tabela 2 estão representados no Gráfico 1 com a variação das valências por ano. As linhas que representam as valências negativas e neutras se mantêm inalteradas até 1998, mas mostram que a totalidade dos editoriais era negativa, indicando que o jornal manteve, no período de 1989 a 1998, uma posição fortemente crítica em relação ao PT e a seus candidatos. E, com a exceção do ano de 2002, essa tendência se mantém, com ligeiras variações, até o pleito de 2014.

\footnotetext{
11 A trégua d'O Globo e da Folha (ver Tabelas 2 e 4), em relação à candidatura de Lula, em 2002, foi antecedida pelo lançamento da "Carta aos brasileiros" pelo PT e assinada pelo candidato, comprometendose com uma política econômica responsável e ortodoxa. Certamente também contribuiu para o armistício a campanha eleitoral de Lula, desenvolvida com um tom político moderado. Ver Azevedo (2017, p. 184).
} 


\section{Gráfico 1}

Editoriais e valências por ano - O Globo (\%)

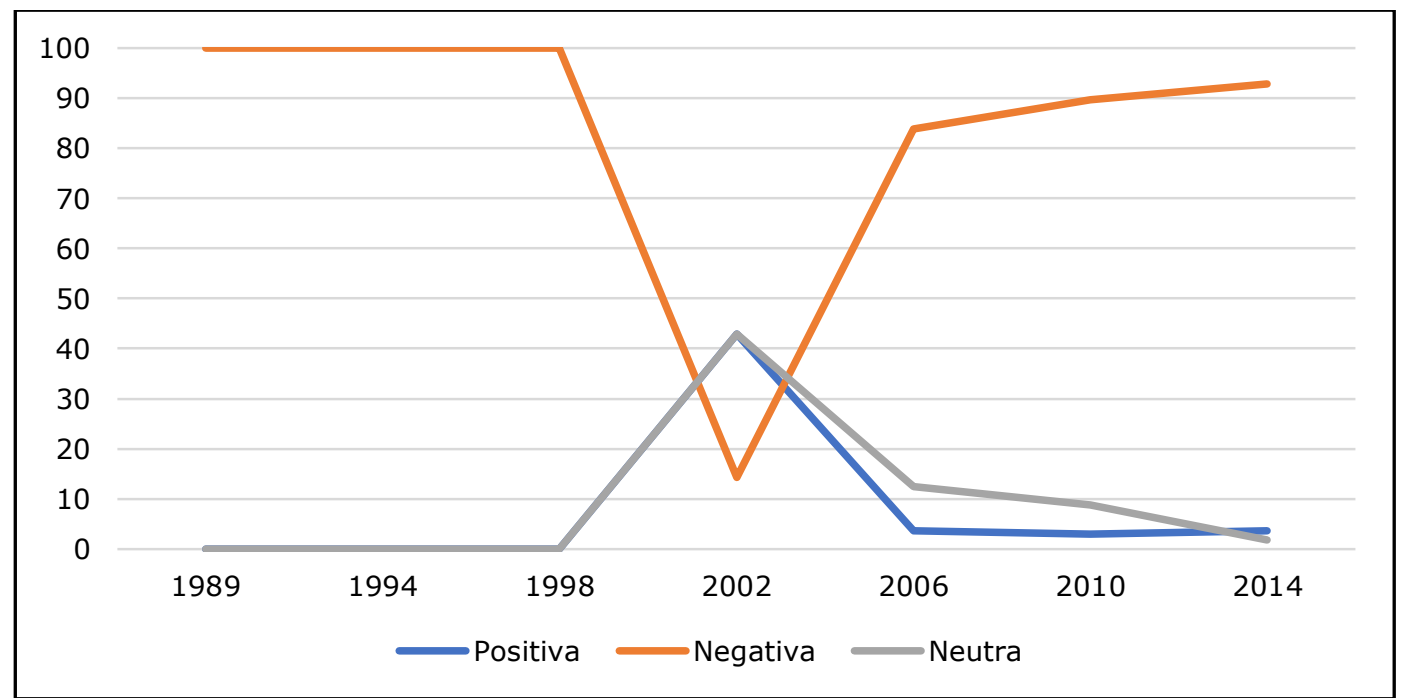

Fonte: Elaboração própria com base em Azevedo (2017).

Entre 1989 e 2002, dos 18 editoriais publicados sobre o PT, quase a metade $(44,4 \%)$ enquadrou de forma negativa o partido e/ou seu principal líder como esquerdista ou populista. Com o PT no poder, o partido e o governo petista se tornaram não só o foco central da atenção da mídia como também telhado de vidro: o jornal carioca publicou dez vezes mais editoriais tendo como objeto o PT, Lula, Dilma e o governo petista. Mas, como se pode ver no Gráfico 2, o enquadramento dominante $(19,4 \%)$ passa a ser o do partido corrupto, narrativa estruturada a partir do escândalo do Mensalão. Esse enquadramento acompanha o grande volume de manchetes e notícias sobre a investigação e o julgamento do Mensalão e seria mantido em 2014 com a Lava Jato. Entre outros enquadramentos observados no segundo período, destaca-se ainda o que caracteriza o domínio petista como um "projeto criminoso de poder" e o "aparelhamento do Estado" (7,2\%) para se perpetuar no controle do país.

Por sua vez, os pacotes interpretativos, que organizavam o enquadramento "populista" ou "corrupto" adotado pelos editoriais, apoiavam-se primariamente no conceito "lulopetista" construído politicamente com forte conotação negativa e usado reiteradamente para caracterizar as ideias e ações do partido e de seus líderes. A expressão "lulopetista" foi criada por colunistas de direita desde a época do escândalo do Mensalão e seu sentido negativo retoma, como um novo significante, significados usados em outros momentos políticos, como a expressão "varguismo", que era empregada para desqualificar politicamente os trabalhistas brasileiros nos anos 1950 ou o populismo sindicalista nos anos 1960 . 
Gráfico 2

Editoriais e pacotes interpretativos - 0 Globo (\%)

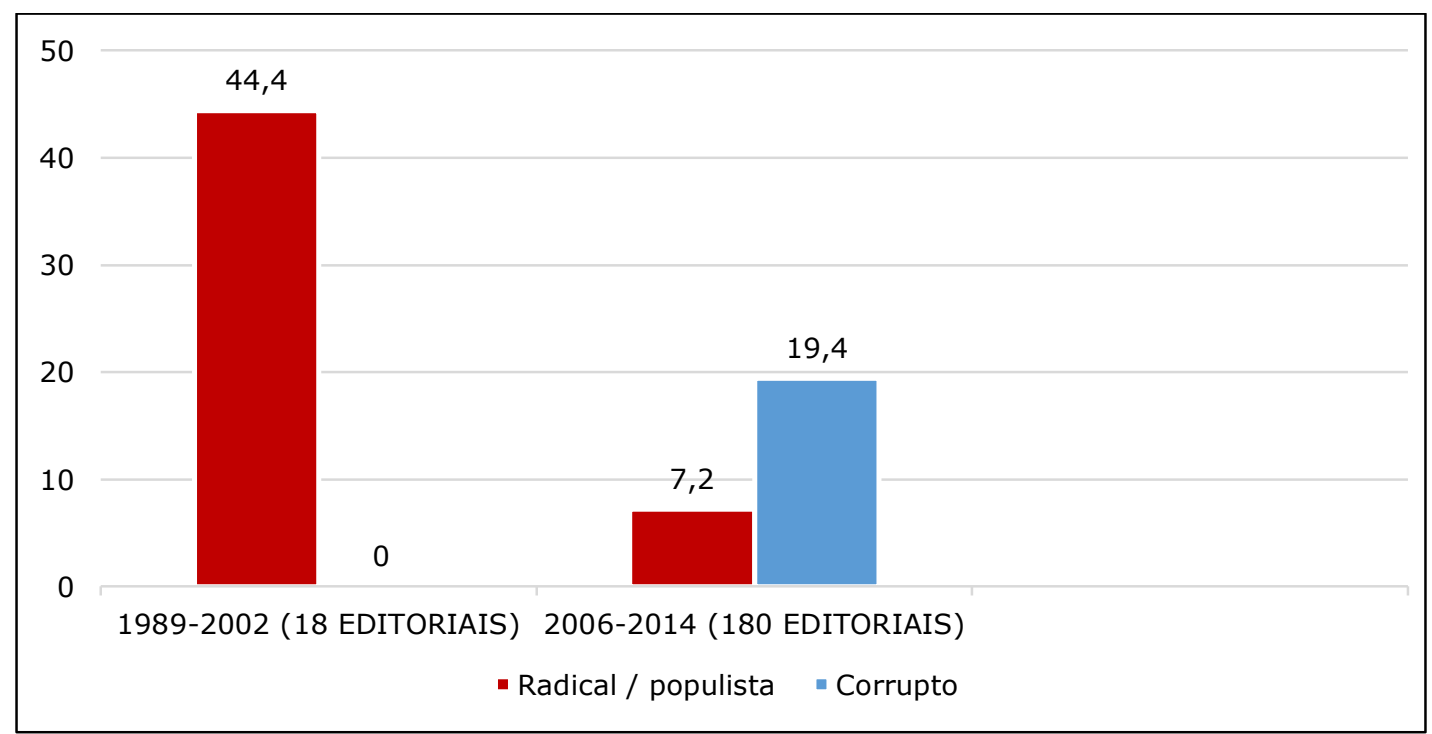

Fonte: Elaboração própria com base em Azevedo (2017).

Os editoriais do Estadão

Dos três jornais pesquisados, o Estadão é o que mais publicou editoriais no período em estudo: 1.453, dos quais 484 foram dedicados a temas ligados ao PT e ao petismo (Tabela 3). Ou seja, o jornal dedicou um terço dos editoriais para abordar temas e questões concernentes aos petistas, mais do que os $25 \%$ dedicados a esses temas pelos seus concorrentes diretos. Por sua vez, as valências de seus editoriais publicados no período foram predominantemente desfavoráveis para o partido liderado por Lula: nada menos do que $90,1 \%$ deles foram negativos contra $2,7 \%$ positivos. Como se vê, a soma de editoriais positivos ou neutros não chegam sequer a $10 \%$. Esses números mostram que, em comparação com os dois outros jornais, o Estadão foi o mais crítico (sendo seguido de perto por $O$ Globo) em relação ao PT e seus governos. 
Tabela 3

Editoriais relacionados ao PT e valência por ano - Estadão

\begin{tabular}{|c|c|c|c|c|c|c|c|c|c|}
\hline \multirow{3}{*}{ Ano } & \multirow{3}{*}{$\begin{array}{c}\text { Número } \\
\text { de } \\
\text { editoriais }\end{array}$} & \multirow{2}{*}{\multicolumn{2}{|c|}{$\begin{array}{c}\text { Relacionados } \\
\text { ao PT }\end{array}$}} & \multicolumn{6}{|c|}{ Valências } \\
\hline & & & & \multicolumn{2}{|c|}{ Positiva } & \multicolumn{2}{|c|}{ Negativa } & \multicolumn{2}{|c|}{ Neutra } \\
\hline & & $\mathbf{N}$ & $\%$ & $\mathbf{N}$ & $\%$ & $\mathbf{N}$ & $\%$ & $\mathbf{N}$ & $\%$ \\
\hline 1989 & 263 & 66 & 25,1 & 0 & 0 & 59 & 89,4 & 7 & 10,6 \\
\hline 1994 & 225 & 23 & 10,2 & 2 & 8,7 & 19 & 82,6 & 2 & 8,7 \\
\hline 1998 & 125 & 9 & 7,2 & 0 & 0 & 9 & 100 & 0 & 0 \\
\hline 2002 & 198 & 33 & 16,7 & 3 & 9,1 & 26 & 78,8 & 4 & 12,1 \\
\hline 2006 & 222 & 131 & 59 & 5 & 3,8 & 122 & 93,1 & 4 & 3,1 \\
\hline 2010 & 222 & 100 & 45 & 2 & 2 & 85 & 85 & 13 & 13 \\
\hline 2014 & 198 & 122 & 61,6 & 1 & 0,8 & 116 & 95,1 & 5 & 4,1 \\
\hline Total & 1.453 & 484 & 33,4 & 13 & 2,7 & 436 & 90,1 & 35 & 7,2 \\
\hline
\end{tabular}

Fonte: Elaboração própria com base em Azevedo (2017).

Os dados comentados no parágrafo anterior podem ser observados no Gráfico 3, que mostra a posição e a trajetória das linhas que representam as valências negativas, positivas e neutras. Como se pode ver, elas praticamente não sofrem oscilações, indicando um posicionamento editorial do jornal coerente ao longo do tempo, ou seja, de oposição ao projeto partidário do PT.

Gráfico 3

Editoriais e valências por ano - Estadão (\%)

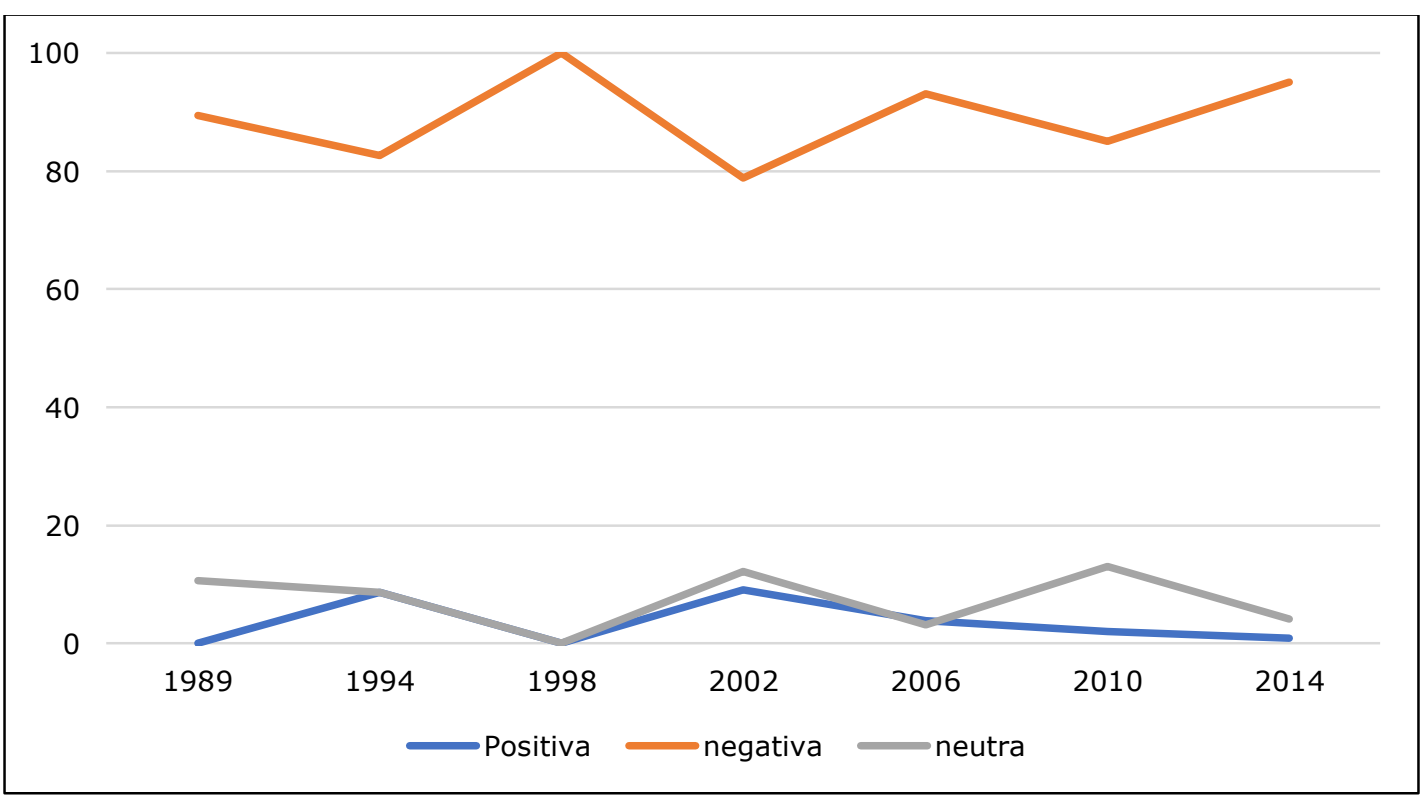

Fonte: Elaboração própria com base em Azevedo (2017).

Em relação aos pacotes interpretativos, o Estadão, como $O$ Globo, usa e pontua com frequência a expressão "lulopetismo" em seus editoriais como um conceito político 
negativo para se referir a ideias, projetos, ações e personagens políticos do partido. Tal como o diário carioca, lança mão dos enquadramentos "radicalismo" e "populismo" no período pré-governo do PT e, após o Mensalão, associa o partido e o governo petista com a corrupção sistêmica do poder.

\section{Gráfico 4}

\section{Editoriais e pacotes interpretativos - Estadão (\%)}

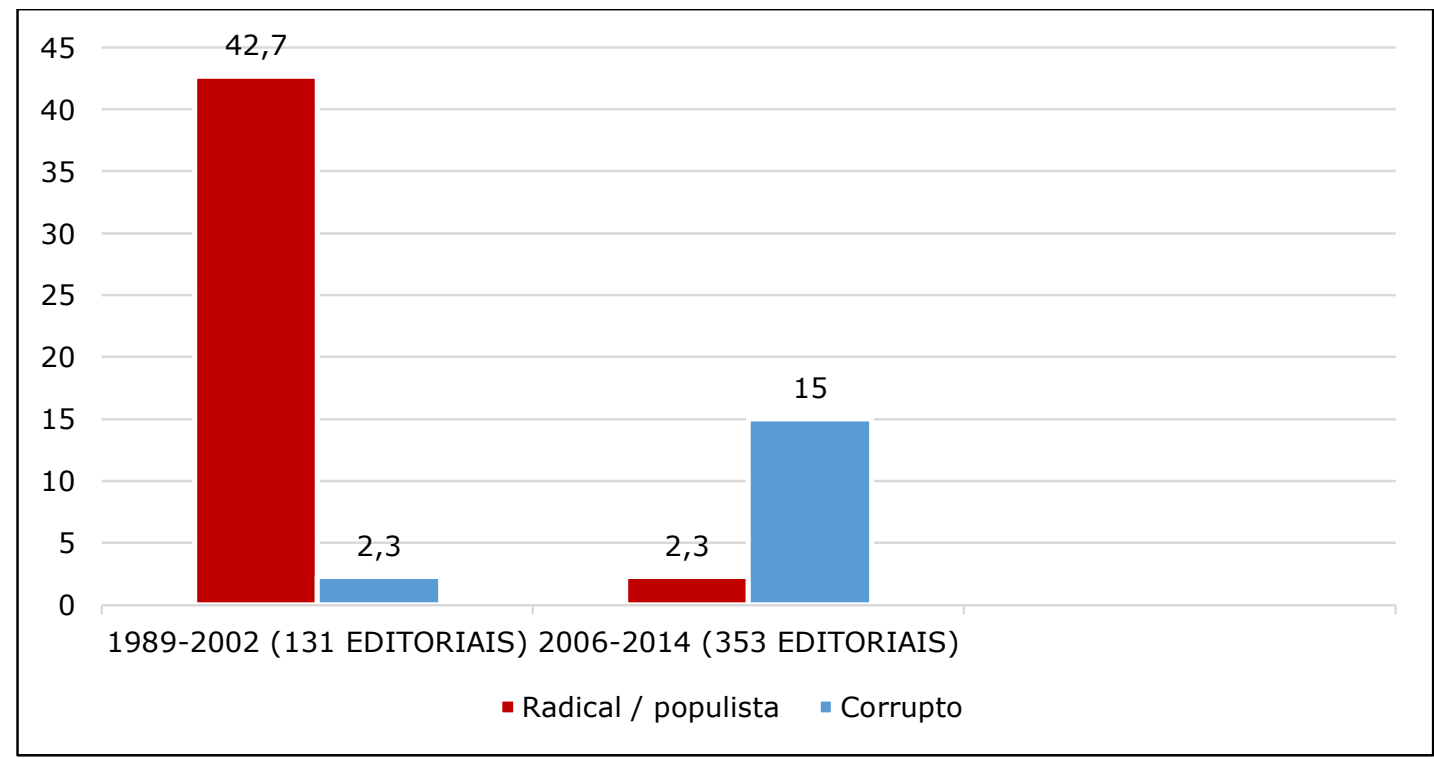

Fonte: Elaboração própria com base em Azevedo (2017).

Editoriais da Folha

A Folha publicou 2 mil editoriais no período pesquisado. Desse montante, 25,5\% abordaram questões relacionadas ao PT, aos dois mandatos de Lula e ao primeiro governo Dilma. Comparado com seus concorrentes, foi o jornal que menos dedicou editoriais aos petistas. E foi, também, o que publicou textos mais neutros $(23,1 \%)$ contra apenas $8,6 \%$ do diário carioca e $7,2 \%$ do seu concorrente paulista. Portanto, nesses dois aspectos, se diferenciou dos dois jornais, mas, por outro lado, convergiu, ainda que em percentual menor, com as outras publicações em relação às valências negativas e positivas: $73,3 \%$ e $3,9 \%$. Esses números e a disparidade entre os editoriais favoráveis e desfavoráveis colocam a Folha como um jornal tão crítico às ações e posições do Partido dos Trabalhadores e de seus governos quanto seus congêneres. Analisando-se os dados por ano, percebe-se que o posicionamento mais crítico se concentra entre 2006 e 2014, ou seja, depois da eclosão do Mensalão em 2005 e no ano do início da Lava Jato. Considerando-se os anos anteriores, os editoriais mais negativos $(65,2 \%)$ ao petismo ocorreram na primeira eleição presidencial direta (1989) após a redemocratização, quando a disputa presidencial foi polarizada, no primeiro turno, entre os dois candidatos da centro- 
PT, ELEIÇÕES E EDITORIAIS DA GRANDE IMPRENSA (1989-2014)

esquerda (Lula e Brizola) e a centro-direita (Collor). Em 1998, o ano eleitoral em que a mídia praticamente ocultou a eleição, embora os editoriais negativos alcançassem o percentual de $100 \%$, o jornal publicou apenas dois editoriais relacionados ao PT.

Tabela 4

Editoriais relacionados ao PT e valência por ano - Folha

\begin{tabular}{|c|c|c|c|c|c|c|c|c|c|}
\hline \multirow{3}{*}{ Ano } & \multirow{3}{*}{$\begin{array}{c}\text { Número } \\
\text { de } \\
\text { editoriais }\end{array}$} & \multirow{2}{*}{\multicolumn{2}{|c|}{$\begin{array}{c}\text { Relacionados } \\
\text { ao PT }\end{array}$}} & \multicolumn{6}{|c|}{ Valências } \\
\hline & & & & \multicolumn{2}{|c|}{ Positiva } & \multicolumn{2}{|c|}{ Negativa } & \multicolumn{2}{|c|}{ Neutra } \\
\hline & & $\mathbf{N}$ & $\%$ & $\mathbf{N}$ & $\%$ & $\mathbf{N}$ & $\%$ & $\mathbf{N}$ & $\%$ \\
\hline 1989 & 276 & 46 & 16,7 & 0 & 0 & 30 & 65,2 & 17 & 37 \\
\hline 1998 & 120 & 2 & 1,7 & 0 & 0 & 2 & 100 & 0 & 0 \\
\hline 2002 & 182 & 26 & 14,3 & 1 & 3,8 & 10 & 38,5 & 15 & 57,7 \\
\hline 2006 & 148 & 62 & 41,9 & 6 & 9,7 & 49 & 79 & 7 & 11,3 \\
\hline 2010 & 142 & 65 & 45,8 & 2 & 3,1 & 52 & 80 & 11 & 16,9 \\
\hline 2014 & 132 & 54 & 40,9 & 1 & 1,9 & 44 & 81,5 & 9 & 16,7 \\
\hline Total & 1.000 & 255 & 25,5 & 10 & 3,9 & 187 & 73,3 & 59 & 23,1 \\
\hline
\end{tabular}

Fonte: Elaboração própria com base em Azevedo (2017).

O Gráfico 5 resume os dados da Tabela 4 por ano eleitoral. Como se pode visualizar, em 2002, num duplo movimento, a linha que representa as valências negativas declina enquanto a linha das valências neutras sobe, indicando que, nesse pleito, o jornal assumiu uma posição de expectativa em relação à candidatura Lula. Nos anos seguintes, as linhas retomam a trajetória do período anterior, expressando a posição crítica do jornal em relação ao petismo e a seus governos.

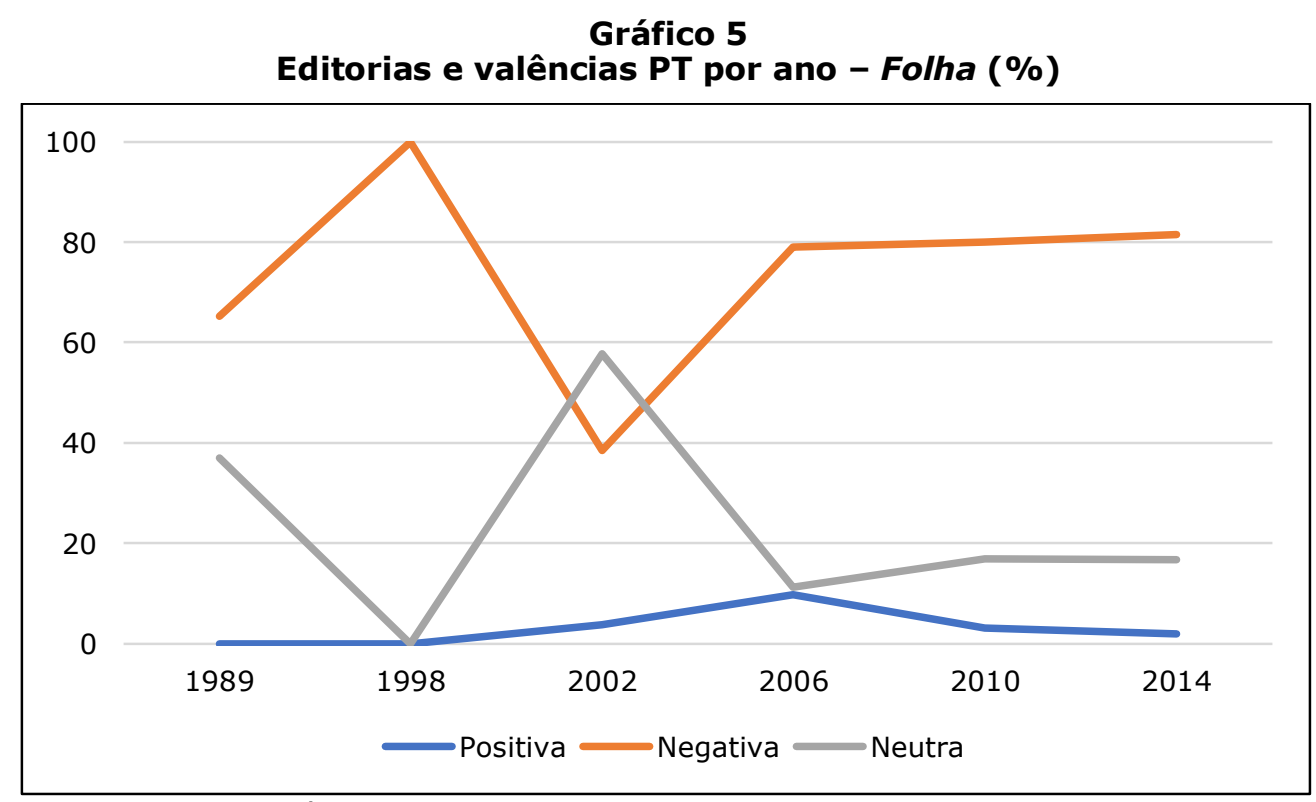

Fonte: Elaboração própria com base em Azevedo (2017). 
A Folha também lançou mão dos mesmos pacotes interpretativos dos seus concorrentes, embora de modo desigual e em menor escala. Como se pode notar no Gráfico 6, no período de ascensão do PT (de 1989 a 2002), o jornal dos Frias praticamente não acionou o enquadramento ideológico "radical/populista", ao contrário dos dois outros diários que, como vimos, acionaram de forma regular e sistemática essa narrativa para caracterizar o Partido dos Trabalhadores. Porém, no período em que o PT estava no poder, a Folha recorre também ao caixilho da "corrupção" para enquadrar o petismo em 25 dos 181 editoriais publicados a partir de 2006.

Gráfico 6

Editoriais e pacotes interpretativos - Folha (\%)

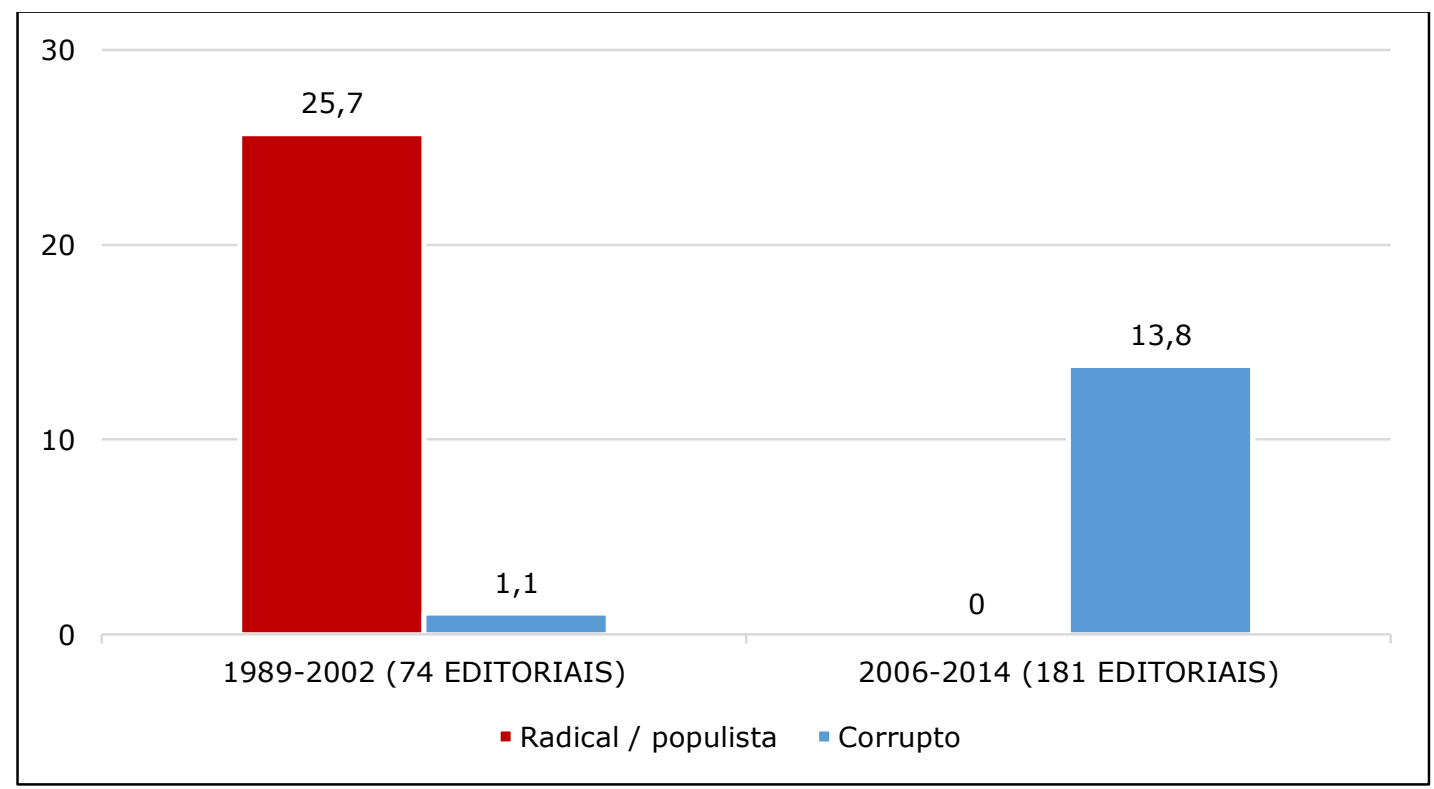

Fonte: Elaboração própria com base em Azevedo (2017).

\section{Conclusão}

Os Gráficos 7 e 8 mostram, para uma rápida visão comparativa, os dados agregados dos jornais em relação às valências negativas e aos pacotes interpretativos usados pelos três jornais. Como se pode constatar, as valências negativas ocupam uma linha praticamente linear e constante desde 1989, mantendo-se sempre acima de $60 \%$, com exceção do ano de 2002. Portanto, a posição crítica dos jornais precede a chegada do PT ao poder e nesse sentido não se pode argumentar que a visão crítica das publicações se deve ao papel fiscalizador do "cão de guarda" (watch dog), que seria próprio da essência da imprensa independente, conforme a teoria liberal do jornalismo. Em outras palavras, os jornais já tinham e mantiveram uma posição fortemente negativa em relação ao petismo desde sua primeira participação no pleito presidencial de 1989. 
Gráfico 7

Editoriais e valências negativas por jornal e ano (\%)

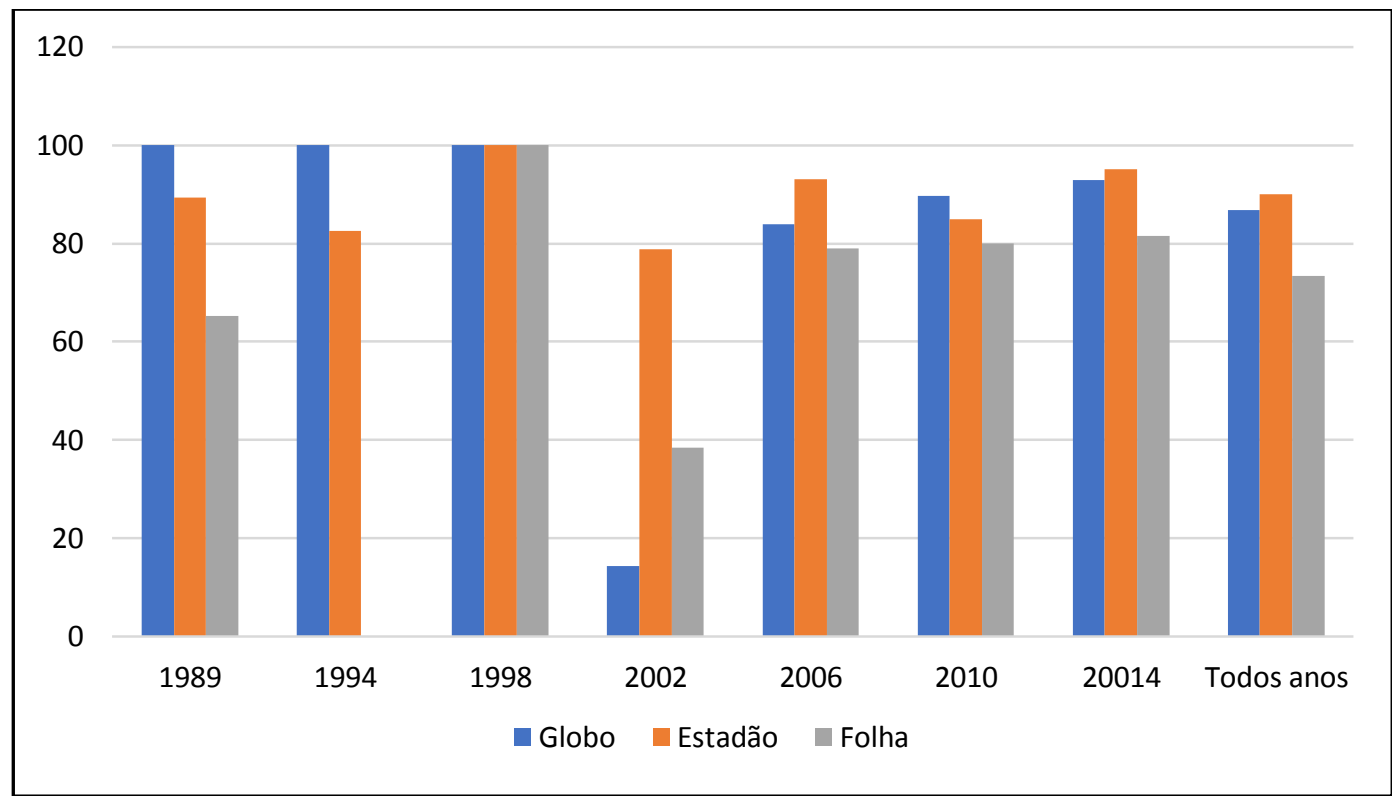

Fonte: Elaboração própria com base em Azevedo (2017).

Porém, como se pode ver no Gráfico 8, as razões dessa posição crítica variam conforme o período analisado. No primeiro período, antes de o PT ascender ao poder, o enquadramento predominante dos jornais ao criticar o partido e o petismo é o seu esquerdismo, usualmente definido como radical e/ou populista. Portanto, um enquadramento de fundo ideológico. Com o PT no governo e depois da eclosão do escândalo do Mensalão, o pacote interpretativo predominante passa a ser o de uma organização corrupta que se utiliza de meios ilícitos para manter o seu projeto de poder, embora o framing anterior de um partido populista seja ainda ocasionalmente acionado. $O$ enquadramento predominante tem, portanto, fundo moral. 


\section{Editoriais e pacotes interpretativos - Folha, Estadão e O Globo (\%)}

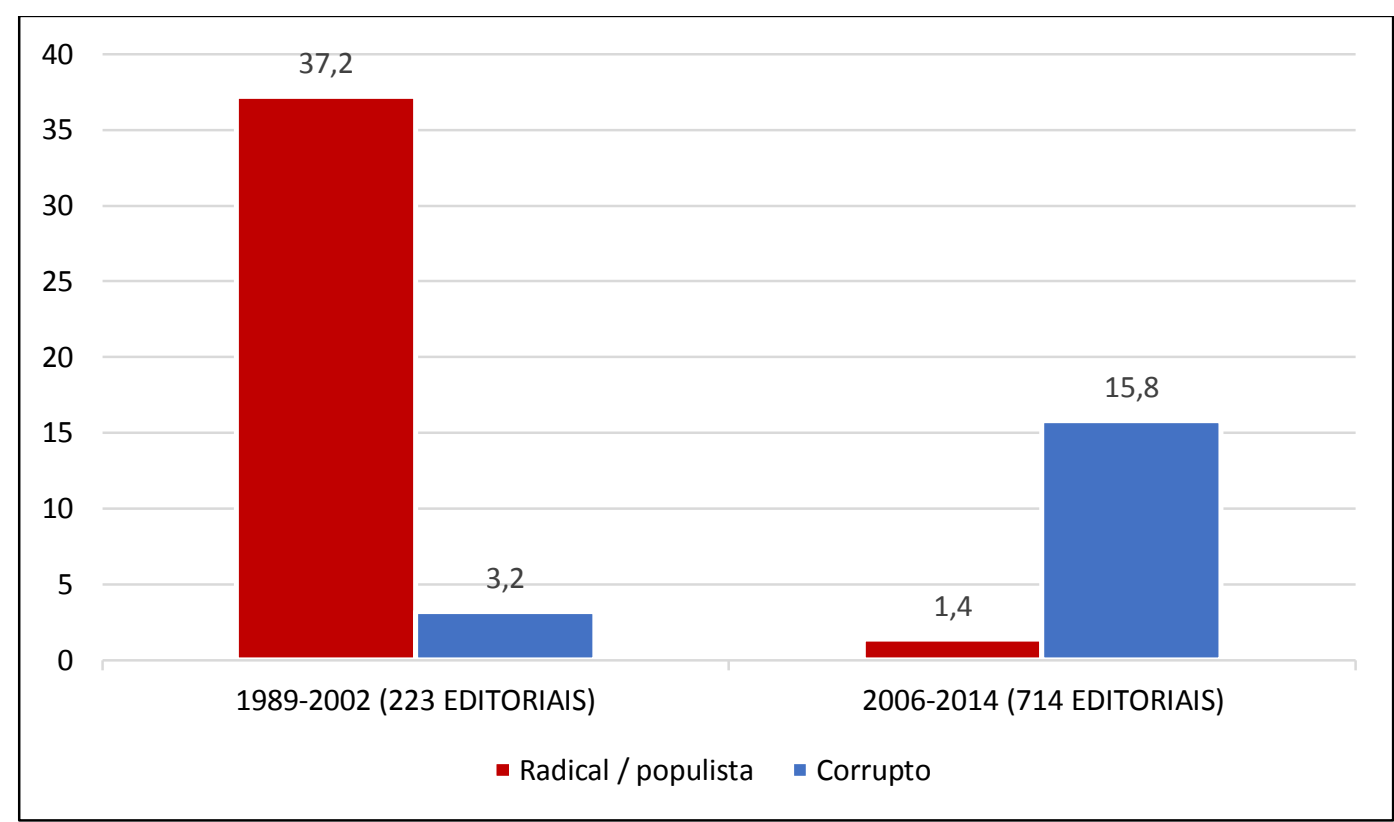

Fonte: Elaboração própria com base em Azevedo (2017).

Em síntese, os dados sobre as valências e os pacotes interpretativos mostram que os editoriais da grande imprensa foram predominantemente negativos, tanto no período pré-governamental quanto no governamental do PT no plano federal, e que os enquadramentos dominantes (radical/corrupto) acionados nos dois momentos estruturaram uma narrativa crítica que, como mostrei em trabalho recente (Azevedo, 2017), foi acionada também no passado contra as forças políticas de centro-esquerda no período do governo democrático de Vargas (1951-1954) e no breve governo Jango (19611964). Nesse sentido, é possível caracterizar a atuação da grande imprensa diária através do conceito de paralelismo político e sugerir que seu antipetismo tem raízes ideológicas, numa visão política liberal que se opõe às ideias nacionalistas, estatistas e desenvolvimentistas do trabalhismo no passado e do petismo no presente.

\section{Referências bibliográficas}

ABReU, A. A imprensa ajudou a derrubar o governo Goulart. In: FerReIRA, M. M. (org.). João Goulart: entre a memória e a história. Rio de Janeiro: Editora FGV, 2008.

AguiAR, C. B. "A imprensa e as eleições de 1989: imagens e atores da política". Comunicação \& Política, vol. 1, n³, p. 179-194, 1995. 
PT, ELEIÇÕES E EDITORIAIS DA GRANDE IMPRENSA (1989-2014)

AlbuQUeRQUe, A. "A campanha presidencial no Jornal Nacional: observações preliminares". Comunicação \& Política, vol. 1, n 1, p. 23-40, 1994.

"O paralelismo político em questão". Compolítica, vol. 2, n 1, p. 6-28, 2012a.

. On models and margins: comparative media models viewed from a Brazilian perspective.

In: HALlin, D.; MANCINI, P. (eds.). Comparing media systems beyond Western world. Cambridge:

Cambridge University Press, p. 72-95, 2012b.

AldÉ, A. "As eleições presidenciais de 2002 nos jornais". Alceu - Revista de Comunicação Cultura e Política, vol. 3, n० 1, p. 23-45, 2003.

AldÉ, A.; Mendes, G.; Figueiredo, M. Imprensa e eleições presidenciais: natureza e consequências da cobertura das eleições de 2002 e 2006. In: LiMA, V. A. (org.). A mídia nas eleições de 2006. São Paulo: Editora Fundação Perseu Abramo, p. 65-87, 2007.

AzeVedo, F. A. Imprensa, campanha presidencial e agenda da mídia. In: Rubim, A. A. C. (ed.). Mídia e eleições 98. Salvador: Edições Facom, p. 31-56, 2000.

. "A imprensa brasileira e o PT: um balanço das coberturas das eleições presidenciais (1989-2006)". Eco-Pós, vol. 12, no 3, p. 41-58, 2009.

. "Eleições presidenciais, clivagem de classe e declínio da grande imprensa". Revista USP, no 90, p. $84-101,2011$.

A grande imprensa e o PT (1989-2014). São Carlos: EdUFSCar, 2017.

BLUMLER, J. G.; GUREVITCH, M. Towards a comparative framework for political communication research. In: BLUMLER, J. G.; GUREVITCH, M. (eds.). The crisis of public communication. London: Routledge, 1975.

CAPElAto, M. R. "Os interpretes das luzes: liberalismo e imprensa escrita paulista - 1920-1945". Tese de Doutorado, Faculdade de Filosofia, Letras e Ciências Humanas da Universidade de São Paulo, São Paulo, 1986.

Imprensa e história no Brasil. São Paulo: Contexto/Edusp, 1988.

Capelato, M. R.; Prado, M. L. R. O bravo matutino. Imprensa e ideologia: o jornal O Estado de S. Paulo. São Paulo: Alfa-Ômega, 1980.

CARVAlho, A. C. O caso da Última Hora e o cerco da imprensa ao governo Vargas. Niterói: Editora da UFF/Nitpress, 2013.

CHAIA, V. Eleições no Brasil: o medo como estratégia política. In: RuBIm, A. A. C. (org.). Eleições presidenciais em 2002 no Brasil - Ensaios sobre mídia, cultura e política. São Paulo: Hackers Editores, p. 29-52, 2004.

CoHen, B. C. The press and foreign policy. Princeton: Princeton University Press, 1963.

DAHL, R. La poliarquía: participación y oposición. Madrid: Editorial Tecnos, 1989.

EILDERS, C. "The impact of editorial content on the political agenda in Germany: theoretical assumptions and open questions regarding a neglected subject in mass communication research" (working paper), 1997. Disponível em: <http://nbn-resolving.de/urn:nbn:de:0168-ssoar-125116>. Acesso em: 16 maio 2016.

ENTMAN, R. "Framing toward a clarification of a fractured paradigm". Journal of Communication, vol. 43 , no 4, p. 51-58, 1993. 
FERES Júnior, J. "Análise de valência, debate acadêmico e contenda política". Revista Brasileira de Ciência Política, n²0, p. 313-322, 2016.

FONSECA, F. O consenso forjado: a grande imprensa e a formação da agenda ultraliberal no Brasil. São Paulo: Hucitec, 2005.

GAMSON, W.; MODigliani, A. "Media discourse and public opinion on nuclear power: a constructionist approach". American Journal of Sociology, vol. 95, n 1, p. 1-37, 1989.

GITLIN, T. The whole world is watching. Berkeley: University of California Press, 1980.

GofFMAN, E. Frame analysis: an essay of the organization of the experience. Boston: Northeastern University Press, 1974.

Goldstein, A. A. De la expectativa a la confrontación: o Estado de S. Paulo durante el primer gobierno de Lula da Silva. Buenos Aires: Sans Soleil Ediciones Argentina, 2015.

. Prensa tradicional y liderazgos populares en Brasil. Raleigh: A Contracorriente, 2017.

Goldstein, G. T. Do jornalismo político à indústria cultural. Rio de Janeiro: Última Hora, 1987.

GuimarãES, C.; Vieira, R. A. A. "Meios de comunicação de massa e eleições: um experimento brasileiro". Comunicação \& Política, vol. 1, nº 9, p. 147-158, 1989.

HALlin, D.; MANCINI, P. Sistemas de mídia: estudo comparativo (três modelos de comunicação e política). Lisboa: Livros Horizontes, 2010.

JORGE, V. L. "Os meios de comunicação de massa nas campanhas eleitorais". Comunicação \& Política, vol. 4, n 1, p. 126-133, 1997.

LANG, K.; LANG, G. E. The mass media and voting. In: Burdick, E.; Brodbeck, A. J. (eds.). American voting behavior. Glencoe: Free Press, p. 217-235, 1959.

LIMA, V. A. "Televisão e política: hipótese sobre a eleição presidencial de 1989". Comunicação \& Política, vol. 9, n 11, p. 29-54, 1990.

MANiN, B. "As metamorfoses do governo representativo". Revista Brasileira de Ciências Sociais, vol. $10, n^{\circ} 29$, p. $1-24,1995$.

Matos, C. Jornalismo e política democrática no Brasil. São Paulo: Publifolha, 2008.

Miguel, L. F. "Mídia e eleições: a campanha de 1998 na Rede Globo". Dados, vol. 42, n 2, p. 253$276,1999$.

Rubim, A. A. C. "Medios, política y elecciones brasileñas de 1989 y 1994". Dia-Logos de la Comunicación, Lima, vol. 1, no 42, p. 18-24, 1985.

Rubim, A. A. C.; Azevedo, F. A. "Mídia e política no Brasil". Lua Nova, n 43, p. 189-216, 1998.

Rubim, A. A. C.; Colling, L. "Mídia e eleições presidenciais no Brasil pós-ditadura". Comunicação \& Política, vol. 22, n³, p. 169-189, 2004.

SeYmour-URE, C. The political impact off mass media. London: Constable/Sage, 1974.

SodrÉ, N. W. História da imprensa no Brasil. Rio de Janeiro: Mauad, 1999. 
PT, ELEIÇÕES E EDITORIAIS DA GRANDE IMPRENSA (1989-2014)

SWANSON, D. L.; MANCINI, P. Politics, media, and modern democracy: international study of innovations in electoral campaigning and their consequences. London: Praeger, 1996.

TASCHNER, G. Folhas ao vento: análise de um conglomerado jornalístico no Brasil. Rio de Janeiro: Paz e Terra, 1992.

\begin{abstract}
The Workers Party in the editorials of the mainstream press (1989-2014)

Departing from the concept of political parallelism, this article examines the relationship between Brazil's "mainstream press", consisting of the three major newspapers in national circulation, namely 1) O Estado de S. Paulo, 2) Folha de S. Paulo, and 3) O Globo, and petismo between 1989 and 2014. Empirical analysis is carried out of editorial pieces focusing on the Workers Party (PT) and its candidates published by these newspapers during the last seven presidential elections. The texts were evaluated using the valence analysis method and grouped into interpretative packages. The results show the predominance of negative editorials and the use of "populism" and/or "corruption" frameworks in the narrative about the PT and petismo both before and after the PT began their government at the federal level.
\end{abstract}

Keywords: media; press; editorials; party; elections; Workers Party; antipetismo

\title{
Resumen
}

EI PT, elecciones y editoriales de la gran prensa (1989-2014)

El artículo examina, a partir del concepto de paralelismo político, la relación de la "gran prensa" de Brasil, formada por los tres principales diarios nacionales, O Estado de S. Paulo, Folha de S. Paulo y O Globo, con el petismo entre 1989 y 2014. La referencia empírica son los editoriales publicados por los periódicos durante las siete últimas elecciones presidenciales teniendo como objeto al PT y sus candidatos. Los textos fueron evaluados a través de la metodología del análisis de valencia y agrupados en paquetes interpretativos. Los resultados muestran el predominio de editoriales negativos y el uso de los encuadres "populistas" y / o "corruptos" en la narrativa sobre el PT y el petismo.

Palabras claves: medios de comunicación; prensa; editoriales; partido; elecciones; PT; antipetismo

\section{Résumé}

Le PT, élections et éditoriaux de la grande presse (1989-2014)

L'article examine, en se fondant sur le concept de parallélisme politique, la relation entre la "grande presse" du Brésil, formée par les trois principaux journaux nationaux de circulation, O Estado de S. Paulo, Folha de S. Paulo et $O$ Globo et le petismo entre 1989 et 2014. La référence empirique réside dans les éditoriaux publiés par les journaux lors des sept dernières élections présidentielles ayant pour objet le PT et ses candidats. Les textes ont été évalués à travers la méthodologie de l'analyse de valência et regroupés dans des ensembles interprétatifs. Les résultats montrent la prédominance des éditoriaux négatifs et l'utilisation des cadrages "populistes" et / ou "corrompus" dans les récits sur le PT et le petismo.

Mots-clés: médias; presse; éditoriaux; parti; élections; PT; antipetismo

Artigo submetido à publicação em 29 de setembro de 2017. Versão final aprovada em 16 de abril de 2018.

Opinião Pública adota a licença Creative Commons CC-BY. 